\title{
Potentiation by Indomethacin of Receptor-Mediated Catecholamine Secretion in Rat Adrenal Medulla
}

\author{
Akira Warashina \\ Department of Physiology, Niigata University School of Medicine, Niigata 951, Japan
}

Received September 2, 1996 Accepted December 9, 1996

\begin{abstract}
Effects of indomethacin on catecholamine secretion evoked by receptor agonists, muscarine, bradykinin or histamine, in rat adrenal chromaffin cells were studied. Indomethacin at $200 \mu \mathrm{M}$ increased a sustained component of secretion during stimulation with muscarine, bradykinin and histamine by a factor of $2.3,2.1$ and 2.9 , respectively, whereas it did not significantly alter basal, high- $\mathrm{K}^{+}$- and nicotine-evoked secretions. Although indomethacin at above $400 \mu \mathrm{M}$ dose-dependently increased basal secretion, the amount of secretion induced by indomethacin alone was much smaller than that in muscarine-evoked secretion as compared at the same concentration of indomethacin applied. Bradykinin-evoked secretion and its potentiation by indomethacin were not inhibited by $20 \mu \mathrm{M}$ nifedipine but were suppressed by $0.5 \mathrm{mM}$ $\mathrm{Ni}^{2+}$. The cyclooxygenase inhibitor, ibuprofen $(200 \mu \mathrm{M})$ did not mimic the effect of indomethacin; prostaglandin $\mathrm{E}_{2}(20 \mu \mathrm{M})$ and arachidonic acid $(100 \mu \mathrm{M})$ did not significantly alter either bradykinin-evoked secretion itself or its potentiation by indomethacin. Bradykinin increased the intracellular free $\mathrm{Ca}^{2+}$ concentration, $\left[\mathrm{Ca}^{2+}\right]_{\mathrm{i}}$, in cells loaded with indo-1, and this response was enhanced in the presence of indomethacin. These results suggest that indomethacin may promote $\mathrm{Ca}^{2+}$ entry to potentiate agonist-evoked catecholamine secretions through a novel action that is not directly related to the inhibition of cyclooxygenase activity with indomethacin.
\end{abstract}

Keywords: Adrenal chromaffin cell (rat), Catecholamine secretion, Indomethacin, Muscarine, Bradykinin

Nicotinic cholinergic transmission from the splanchnic nerves plays a central role in catecholamine (CA) secretion from adrenal medullary cells. However, the stimulation of non-nicotinic receptor agonists such as muscarine, bradykinin and histamine also evokes CA secretion in the perfused rat adrenal gland $(1-6)$. These agonists promote phosphoinositide metabolism in chromaffin cells $(7,8)$. In many cell types, agonist-induced phosphoinositide metabolism is accompanied by the activation of phospholipase $A_{2}$ to release arachidonic acid (9). Thus, there occurs the possibility that arachidonic acid metabolism may participate in the regulation of secretory processes in chromaffin cells. Although this possibility has been tested by various investigators, reported effects of phospholipase $A_{2}$ inhibitors $(10,11)$, arachidonic acid $(12-15)$, cyclooxygenase inhibitors $(16,17)$ and prostaglandins $(17-21)$ on secretory responses have not yet provided a clear view on the role of arachidonic metabolism in regulation of CA secretion in chromaffin cells.

In this study, experiments were carried out to obtain further information to assess the role of arachidonic acid metabolism in CA secretion in rat chromaffin cells. During the course of the study, I found that indomethacin markedly potentiates receptor-mediated CA secretions. Thus, this indomethacin effect was studied in detail to determine if it derived from the inhibition of cyclooxygenase activity by this drug. Results obtained suggest that indomethacin enhances $\mathrm{Ca}^{2+}$ entry in agonist-stimulated chromaffin cells by a mechanism that is not directly associated with the inhibition of cyclooxygenase. This novel action of indomethacin may be useful for investigating the mechanism of $\mathrm{Ca}^{2+}$ entry during receptor stimulation in chromaffin cells and other cell types.

A preliminary report of this study has appeared in abstract form (22).

\section{MATERIALS AND METHODS}

\section{Chemicals and solutions}

Muscarine, prostaglandin $\mathrm{E}_{2}\left(\mathrm{PGE}_{2}\right)$, arachidonic acid and nifedipine were purchased from Sigma Chemical (St. Louis, MO, USA). Indo-1 AM, fura-2 AM and HEPES 
were from Dojin Laboratory (Kumamoto). Pluronic F127 was from Behring Diagnostics (La Jolla, CA, USA). Bradykinin was from Peptide Institute (Minoh). Calcium Green-1 AM was from Molecular Probes (Eugene, OR, USA). Histamine, indomethacin, ibuprofen, neostigmine and inorganic chemicals were from Wako Pure Chemical (Osaka). The standard medium to perfuse isolated rat adrenal glands was a modified Krebs solution that consisted of $150 \mathrm{mM} \mathrm{NaCl}, 5.6 \mathrm{mM} \mathrm{KCl}, 2 \mathrm{mM} \mathrm{CaCl}_{2}, 1 \mathrm{mM}$ $\mathrm{MgCl}_{2}, 5.6 \mathrm{mM}$ glucose and $1 \mathrm{mM} \mathrm{NaH} \mathrm{PO}_{4}-10 \mathrm{mM}$ HEPES buffered at $\mathrm{pH} 7.4$ by titration with $\mathrm{NaOH}$. Concentrated solutions of indomethacin, ibuprofen, $\mathrm{PGE}_{2}$, arachidonic acid and nifedipine were prepared in dimethyl sulfoxide and diluted in the standard medium. The final concentration of dimethyl sulfoxide was either $0.1 \%$ or $0.2 \%$, which did not affect secretory or intracellular free calcium concentration $\left(\left[\mathrm{Ca}^{2+}\right]_{i}\right)$ responses evoked by the receptor agonists.

\section{Monitoring of $C A$ secretion}

CA secretion from the isolated rat adrenal gland was continuously detected by the previously described method (3). In brief, adrenal glands were isolated from male Wistar rats $(340-430 \mathrm{~g})$ anesthetized by i.p. injection of pentobarbital $(50 \mathrm{mg} / \mathrm{kg})$. The gland was perfused retrogradely at a rate of $0.15 \mathrm{ml} / \mathrm{min}$ with the standard medium through a cannula inserted into the adrenal vein. The perfusate was then let into a flow cell (TL-5; Bioanalytical Systems, West Lafayette, IN, USA) in which glassy carbon electrodes were installed. The amount of CA in the perfusate was measured with an amperometric detector (VMD-101A; Yanaco, Kyoto) at an applied electrode voltage of $0.4 \mathrm{~V}$. The intensity of oxidation current that is proportional to the amount of CA in the perfusate was subjected to 12-bit A/D conversion and recorded on a magnetic disk. Figures presented in this paper were drawn by an $\mathrm{X}-\mathrm{Y}$ recorder with data saved on the magnetic disk.

Experiments were carried out at room temperatures $\left(24-27^{\circ} \mathrm{C}\right)$.

For quantitative evaluations, response sizes were calculated numerically using stored data and were then converted into moles of CA based on a calibration relation obtained with adrenaline standard solution.

Statistical differences between means of CA secreted during determined periods were calculated by Student's $t$-test for non-paired data. Level of significance was established at the value of $\mathbf{P}<0.05$.

\section{Measurement of changes in $\left[\mathrm{Ca}^{2+}\right]_{i}$}

Changes in $\left[\mathrm{Ca}^{2+}\right]_{\mathrm{i}}$ arising in chromaffin cells in the perfused rat adrenal medulla were measured as described in a previous paper (23). The adrenal gland was perfused for $60 \mathrm{~min}$ recurrently with $2 \mathrm{ml}$ of the standard medium containing indo- $1 \mathrm{AM}$ at $10 \mu \mathrm{M}, 0.1 \%$ of Pluronic F- 127 and $20 \mu \mathrm{M}$ neostigmine to load chromaffin cells with the indicator dye. About half of the adrenal cortex was then removed by dissection and the exposed portion of adrenal medulla under the perfused condition was placed in a measurement chamber on the stage of an inverted fluorescence microscope (IMT-2; Olympus, Tokyo). A light from a xenon lamp (XBO $100 \mathrm{~W}$; Osram, Munich, Germany) was transmitted by a $350 \mathrm{~nm}$ bandpass filter mounted on a pulse motor-controlled chopper wheel and focused onto a small portion of the exposed medulla with a $\times 20$ objective. Indo-1 fluorescent light excited at 350 $\mathrm{nm}$ was divided with a $450 \mathrm{~nm}$ dichroic mirror to permit simultaneous measurement of both 405 and $480 \mathrm{~nm}$ lights using two photomultiplier tubes. Changes in the $405 / 480$ $\mathrm{nm}$ fluorescence intensity ratio represent changes in $\left[\mathrm{Ca}^{2+}\right]_{\mathrm{i}}$ (24).

Data obtained by the fluorometry were stored on a magnetic disk with a system similar to that used for secretion experiments.

\section{RESULTS}

\section{Effects of indomethacin on muscarine-evoked CA secre-} tion

A continuous 18-min stimulation of a perfused adrenal gland of the rat with $100 \mu \mathrm{M}$ muscarine evoked a biphasic secretory response, an initial transient followed by a sustained secretion as shown in Fig. 1Aa. The presence of 200 and $800 \mu \mathrm{M}$ indomethacin in the perfusate from the 6 th to 12 th min during the 18 -min stimulation with muscarine markedly potentiated the sustained secretion as displayed in Fig. 1 A, b and c, respectively. The increase of muscarine-evoked CA secretion by indomethacin was evaluated as illustrated in Fig. 1Ab. Namely, the response in the period during which indomethacin was applied (between the 6th and 12th $\mathrm{min}$ ) was separated into the two parts, area $\mathrm{A}$ and area $\mathrm{S}$, by the line $\mathrm{L}$. The indomethacin effect is expressed either by the amount of increased secretion calculated from the area $\mathrm{A}$ or by the fractional increase of secretion, $(1+\mathrm{A} / \mathrm{S})$. The slope of line $\mathrm{L}$, being $-1.6 \pm 0.9 \%$ per min (mean \pm S.E., $n=5$ ), was obtained from control data such as that shown in Fig. $1 \mathrm{Aa}$.

The indomethacin-induced increase of muscarineevoked CA secretion was calculated from the area $\mathrm{A}$ and is plotted, as a function of indomethacin concentration, by the filled circles in Fig. 1B. Marked increases of the secretion occurred with indomethacin at concentrations above $100 \mu \mathrm{M}$. The increase seems to level off at indomethacin concentrations higher than $1.6 \mathrm{mM}$, although no such experiments were carried out because of the limitation of indomethacin solubility.

The solid line in Fig. 1B was drawn based on the Hill 
$\mathbf{A}$

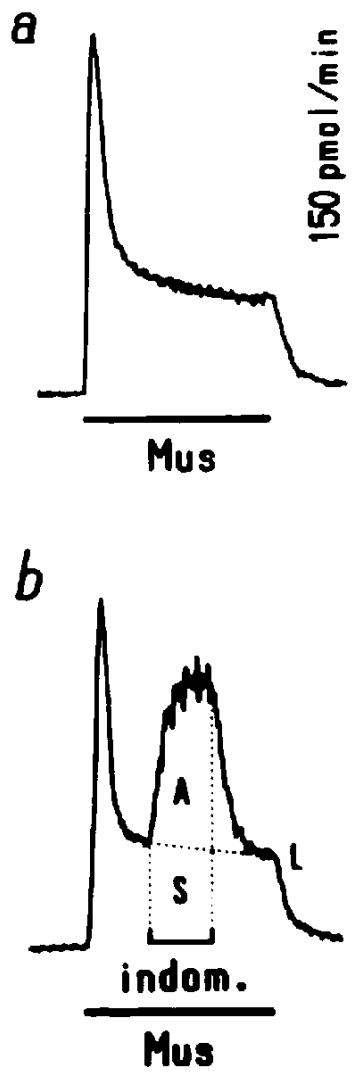

B

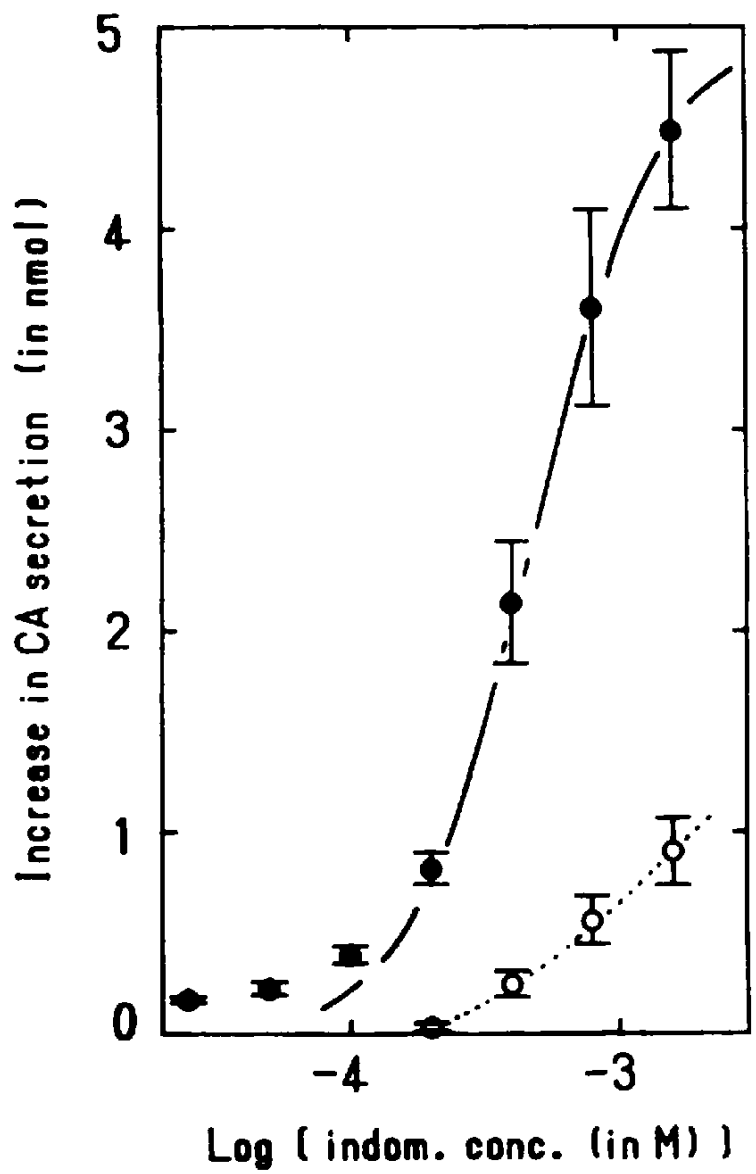

Fig. 1. Potentiation by indomethacin of muscarine-evoked CA secretion. Aa: Change in the intensity of oxidation current produced by CA secreted from a rat adrenal gland during a 18 -min stimulation with $100 \mu \mathrm{M}$ muscarine (Mus). b and c: Potentiation of muscarine-evoked secretion with 200 and $800 \mu \mathrm{M}$ indomethacin (indom.), respectively. In either experiment, indomethacin was applied between the 6th and 12th min during a 18 -min stimulation with $100 \mu \mathrm{M}$ muscarine. The periods of applications of muscarine and indomethacin are indicated underneath the traces. The three records were taken with the same gland. A 30-min resting period was inserted after each of the measurements in $a$ and $b$. To evaluate the indomethacin effect, the response in the period between the 6th and 12th min was separated into the two parts, area $A$ and area $S$, by the line $L$ (in b). The vertical scale, which applies to all three traces in panel A, indicates secretion of CA at a rate of $150 \mathrm{pmol} / \mathrm{min}$. B: Increases in muscarine-evoked secretion with various concentrations of indomethacin were evaluated by the response area $A$ and are plot ted by the filled circles. Open circles represent increases in the basal CA secretion during a 6-min application of indomethacin alone. The data used for this analysis were collected from 47 determinations with 18 glands. Data plotted are each expressed as a mean \pm S.E. $(n=4$ or 5$)$.

equation with the coefficient of 1.9 , which was determined by a least-squares fitting of the data points obtained with indomethacin at concentrations above 100 $\mu \mathrm{M}$. This analysis indicates that the dose of indomethacin for the half-maximal effect is $460 \mu \mathrm{M}$, where the fractional increase of the muscarine-evoked secretion is close to 5 .

The rate of basal CA secretion in the perfused rat adrenal gland at room temperatures was lower than 5 $\mathrm{pmol} / \mathrm{min}$ (23). Indomethacin at concentrations below $200 \mu \mathrm{M}$ had a negligible effect on the basal level as shown in Fig. 2a. However, indomethacin alone induced CA secretion in a dose-dependent manner at concentrations above $400 \mu \mathrm{M}$; the open circles in Fig. 1B show the amount of CA secreted during a 6-min application of indomethacin at concentrations indicated by the abscissa. The indomethacin-induced secretion above the basal level was much smaller than the indomethacin-induced increase in muscarine-evoked secretion as shown in Fig. 1B.

The effect of indomethacin on CA secretion evoked by various stimulants

In rat adrenal chromaffin cells, receptor agonists such as muscarine, bradykinin and histamine evoke CA secre- 
a

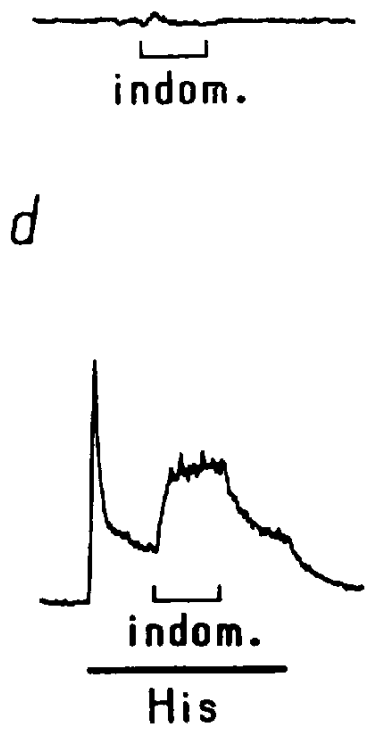

$b$
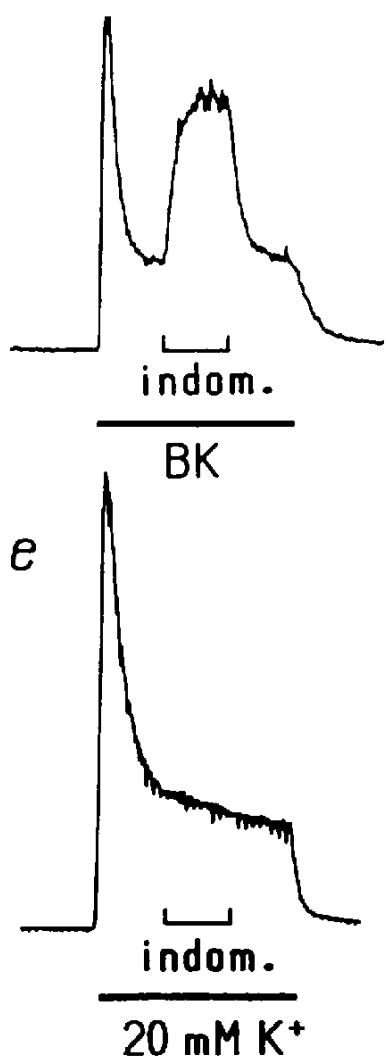

C
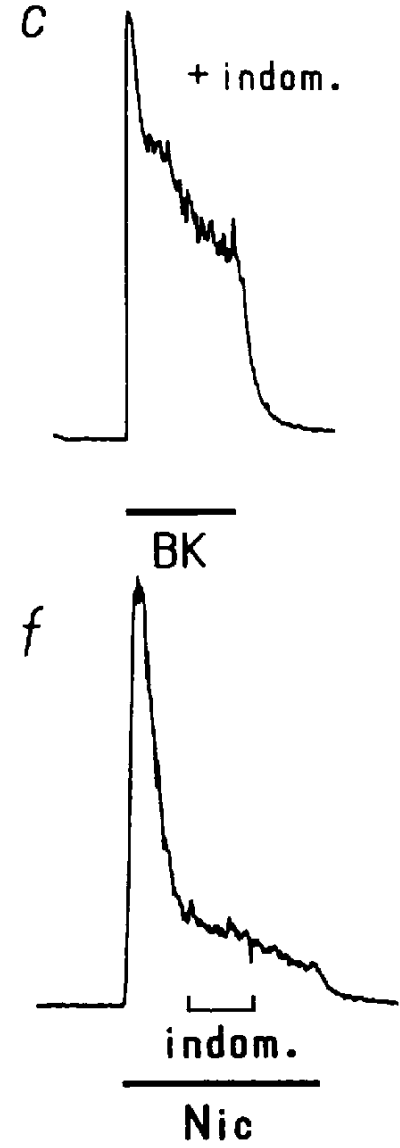

Fig. 2. Effects of $200 \mu \mathrm{M}$ indomethacin on CA secretions evoked by various secretagogues. a: Influence of indomethacin (indom.) on the basal secretion. b: Indomethacin was applied between the 6th and 12th min during a 18-min stimulation with $200 \mathrm{nM}$ bradykinin (BK). c: Indomethacin was present from 5 min prior to the 10 -min stimulation with $200 \mathrm{nM}$ bradykinin to the end of the measurement. $d$, e and f: Indomethacin was applied between the 6th and 12th min during a 18-min stimulation with $100 \mu \mathrm{M}$ histamine (His), $20 \mathrm{mM}$ extracellular $\mathrm{K}^{+}$and $10 \mu \mathrm{M}$ nicotine (Nic), respectively. The vertical and horizontal scales at panel a apply to all of the traces in this figure. Two or three tests with different secreatagogues were carried out with one gland. Each trace is representative of four consistent results.

tion, of which characteristics are similar in many aspects $(3-5)$. When $200 \mu \mathrm{M}$ indomethacin was administered between the 6th and 12th min during a 18-min stimulation with $200 \mathrm{nM}$ bradykinin or $100 \mu \mathrm{M}$ histamine, a large increase in the secretion occurred as shown in Fig. $2 b$ or $2 \mathrm{~d}$, respectively. The extent of indomethacin-induced increases in terms of $(1+A / S)$ is $2.1 \pm 0.1(n=4)$ for bradykinin and $2.9 \pm 0.4(n=4)$ for histamine, which are comparable with $2.3 \pm 0.1(n=4)$ for muscarine-evoked secretion. In the experiment shown in Fig. $2 c$, cells were pretreated for 5 min with $200 \mu \mathrm{M}$ indomethacin, and then a 10-min stimulation with $200 \mathrm{nM}$ bradykinin was delivered in the continued presence of indomethacin. Indomethacin potentiated the bradykinin-evoked secretory response over the entire period of stimulation with a significant change in its time-course.

In sharp contrast to the response evoked by these receptor agonists, CA secretion elicited by an elevation of extracellular $\mathrm{K}^{+}$concentration to $20 \mathrm{mM}$ was not altered by $200 \mu \mathrm{M}$ indomethacin as shown in Fig. 2e. Similarly, CA secretion evoked by $10 \mu \mathrm{M}$ nicotine is not potentiated by $200 \mu \mathrm{M}$ indomethacin (Fig. 2f). Although the secretion evoked by high- $\mathrm{K}^{-}$was increased during application of indomethacin at concentrations above $400 \mu \mathrm{M}$, the increase was comparable with the amount of secretion induced by indomethacin alone at the tested concentrations of the drug (for the latter, see the open circles in Fig. 1B).

Effects of various agents on bradykinin-evoked $C A$ secretion and its potentiation by indomethacin

Indomethacin is well known as a cyclooxygenase inhibitor. Thus, whether the observed effects of indomethacin on secretory responses were related to cyclooxygenase metabolism or not was assessed. At first, the 
a

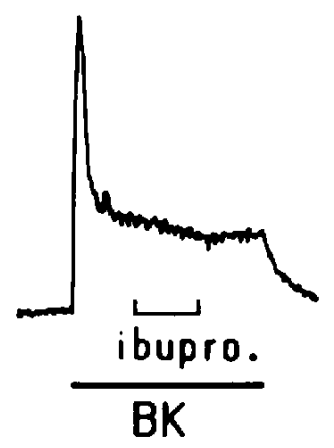

$d$

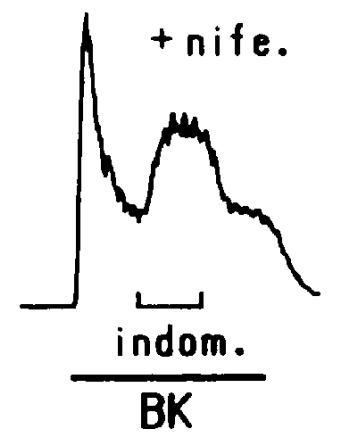

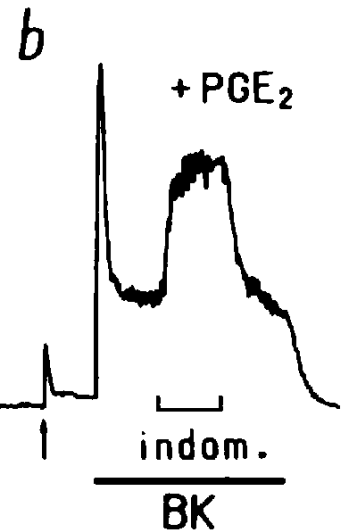

$e$

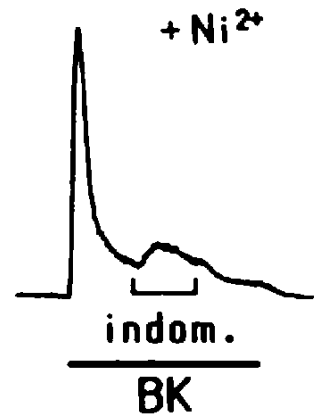

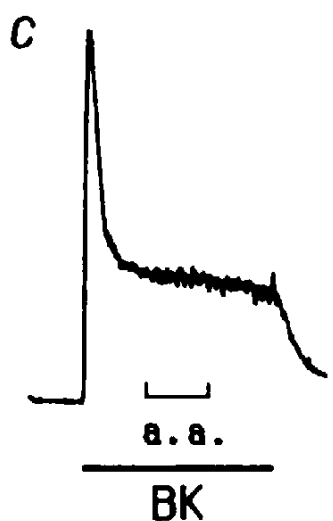

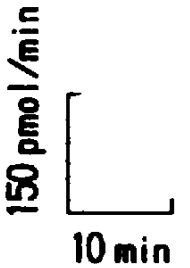

Fig. 3. Effects of various agents on bradykinin-evoked secretion and its increase by indomethacin. The following agents were applied between the 6 th and 12 th min during a 18 -min stimulation with $200 \mathrm{nM}$ bradykinin (BK). a: $200 \mu \mathrm{M}$ ibuprofen (ibupro.); b: $200 \mu \mathrm{M}$ indomethacin (indom.) in the presence of $20 \mu \mathrm{M} \mathrm{PGE} 2$. The $\mathrm{PGE}_{2}$ treatment commenced 5 min prior to the bradykinin stimulation (indicated by the arrowhead); c: $100 \mu \mathrm{M}$ arachidonic acid (a.a.); $\mathrm{d}: 200 \mu \mathrm{M}$ indomethacin in the presence of $20 \mu \mathrm{M}$ nifedipine (nife.); e: $200 \mu \mathrm{M}$ indomethacin in the presence of $0.5 \mathrm{mM} \mathrm{Ni}^{2+}$. The vertical and horizontal scales apply to all of the traces in this figure. Each trace is representative of four consistent results from different glands.

effect of ibuprofen, another cyclooxygenase inhibitor, was tested in the period between the 6th and 12th min during a 18-min stimulation with bradykinin as shown in Fig. 3a. Unlike indomethacin, $200 \mu \mathrm{M}$ ibuprofen did not promote the bradykinin-evoked secretion. Ibuprofen at $400 \mu \mathrm{M}$ was also ineffective for promoting bradykininevoked secretion (data not shown).

In the experiment shown in Fig. $3 \mathrm{~b}$, the effect of $20 \mu \mathrm{M}$ $\mathrm{PGE}_{2}$ on indomethacin-induced increase in bradykininevoked secretion was studied. The application of $\mathrm{PGE}_{2}$, commenced at $5 \mathrm{~min}$ before the bradykinin stimulation (indicated by the arrowhead), produced a small secretory response. The continued presence of $\mathrm{PGE}_{2}$, however, did not affect either bradykinin-evoked secretion or its increase by indomethacin. The fractional increase of the bradykinin-evoked secretion due to $200 \mu \mathrm{M}$ indomethacin in the presence of $\mathrm{PGE}_{2}$ is $2.3 \pm 0.1(\mathrm{n}=4)$, which does not significantly differ from the corresponding value in the absence of the exogenous $\mathrm{PGE}_{2}(\mathrm{P}>0.05, t$-test $)$.
Moreover, $100 \mu \mathrm{M}$ arachidonic acid applied during stimulation with bradykinin had no effect (Fig. 3c).

Effects of ibuprofen $(200 \mu \mathrm{M}), \mathrm{PGE}_{2}(20 \mu \mathrm{M})$ and arachidonic acid $(100 \mu \mathrm{M})$ on muscarine-evoked secretion were examined with the same protocol as in the experiments with bradykinin. Although only a single experiment with each agent was performed, no essential difference was recognized as compared with the results obtained with bradykinin. Although the doses of the above agents to assess their effects were not chosen on rigorous bases, the concentrations used are considered to be high enough for observing their effects, if they exist. Thus, the above results suggest that the promoting effect of indomethacin on receptor-mediated CA secretions is not derived from the inhibition of cyclooxygenase activity but from a novel effect of the drug.

At least two pathways of $\mathrm{Ca}^{2+}$ entry are involved in the secretory responses of rat chromaffin cells. One involves voltage-gated $\mathrm{Ca}^{2+}$-channels that play an essential role 
when cells respond to depolarizing stimulants such as nicotinic agents and excess extracellular $\mathrm{K}^{+}$. The other pathway is used for receptor-mediated $\mathrm{Ca}^{2+}$ entry that supports CA secretion evoked by agonists such as muscarine, bradykinin and histamine. In Fig. 3d, the effect of indomethacin on bradykinin-evoked CA secretion was examined in the presence of $20 \mu \mathrm{M}$ nifedipine, which effectively blocks voltage-gated $\mathrm{Ca}^{2+}$ channels in chromaffin cells $(3,4)$. In the presence of nifedipine, bradykinin-evoked CA secretion was slightly reduced: $88 \pm 9 \%(n=4)$ of the control when evaluated by the amount of CA secreted during the initial 6-min stimulation. However, the fractional increase as the index of the indomethacin effect is calculated to be $1.9 \pm 0.1(n=4)$, which does not significantly differ from that in the absence of nifedipine ( $P>0.05, t$-test).

Receptor-mediated $\mathrm{Ca}^{2+}$-entry in chromaffin cells is effectively blocked by $\mathrm{Ni}^{2+}(25)$. The extent of inhibition of bradykinin-evoked secretion by $0.5 \mathrm{mM} \mathrm{Ni}^{2+}$ depended on the phase of the secretory response, showing $18 \%$ inhibition in the initial phase of secretion, whereas $75 \%$ inhibition occurred in the sustained phase. As shown in Fig. 3e, the sustained secretion evoked by bradykinin as well as its increase by indomethacin were extensively suppressed.

The results obtained with nifedipine and $\mathrm{Ni}^{2+}$ are compatible with the idea that indomethacin potentiates agonist-evoked CA secretion by increasing receptor-
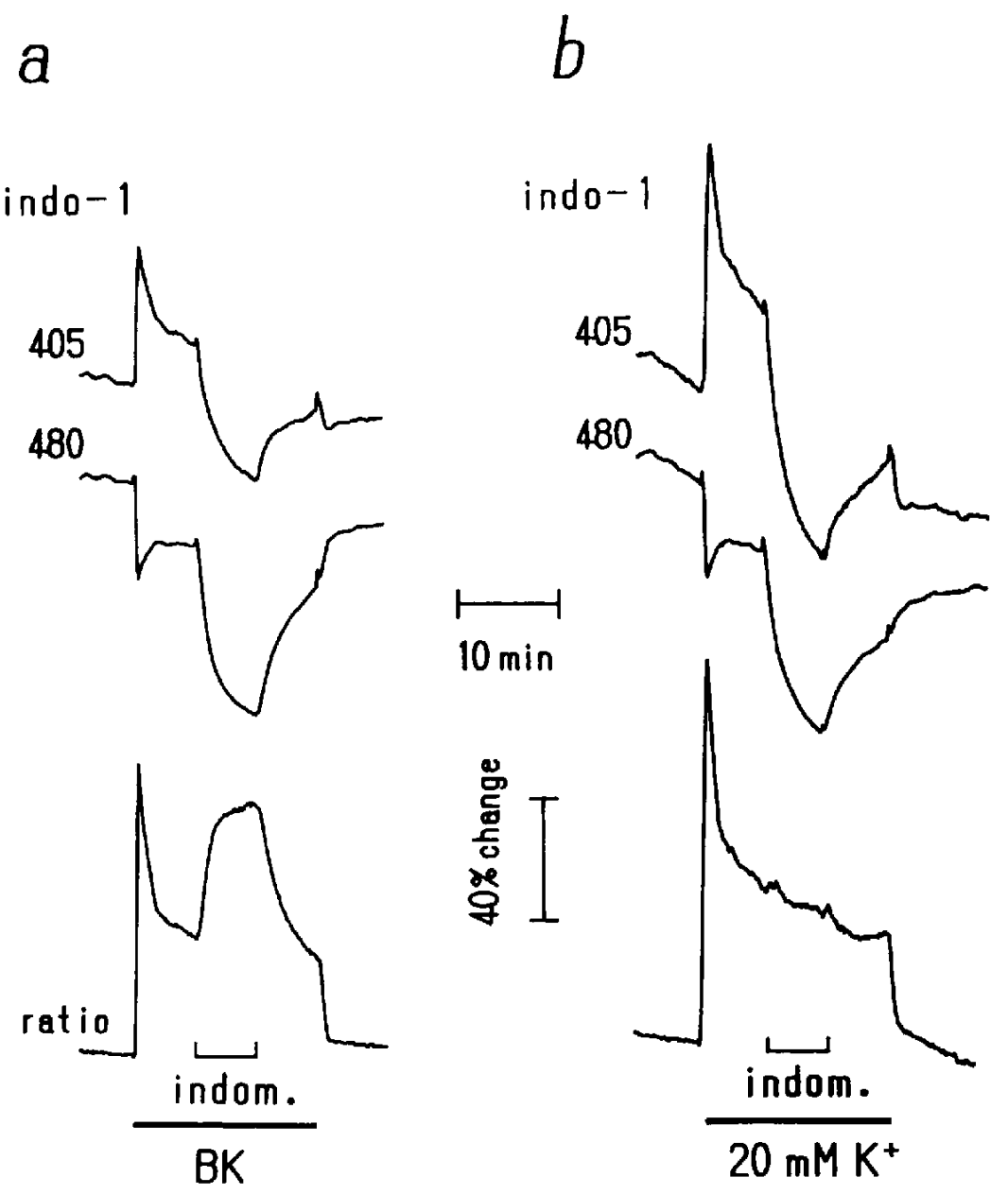

Fig. 4. Effects of indomethacin on $\left[\mathrm{Ca}^{2+}\right]_{i}$ change induced by bradykinin and excess extracellular $\mathrm{K}^{+}$in indo-1-loaded chromaffin cells of the perfused rat adrenal medulla. a: Indomethacin (indom., $200 \mu \mathrm{M}$ ) was applied between the 6 th and 12 th min during a 18-min stimulation with $200 \mathrm{nM}$ bradykinin (BK). The top and middle traces respectively show changes in intensities of indo- 1 fluorescence at 405 and $480 \mathrm{~nm}$. The trace at the bottom indicates the ratio of intensities of 405 to $480 \mathrm{~nm}$ fluorescence. b: A set of the three traces obtained with the same experimental protocol as in panel a except that $20 \mathrm{mM} \mathrm{K} \mathbf{K}^{+}$, instead of bradykinin, was used as a secretagogue. The vertical scale, which applies to both traces at the bottom in panels a and $\mathrm{b}$, indicates a $40 \%$ change in the fluorescence intensity ratio with respect to the resting levels. The records are representative of four consistent results from different glands. 
mediated $\mathrm{Ca}^{2+}$ entry.

The influences of indomethacin on agonist-induced changes in $\left[\mathrm{Ca}^{2+}\right]_{i}$

In Fig. 4a, indo-1-loaded chromaffin cells were stimulated for $18 \mathrm{~min}$ by $200 \mathrm{nM}$ bradykinin, during which 200 $\mu \mathrm{M}$ indomethacin was applied from the 6th to 12 th $\mathrm{min}$. The intensity of indo- 1 fluorescence emitted at either 405 or $480 \mathrm{~nm}$ decreased during application of indomethacin most likely due to absorption of $350 \mathrm{~nm}$ (excitation wave length for indo-1) light with indomethacin that was accumulated in the chromaffin cells (top and middle traces in Fig. 4a). However, the $405 / 480 \mathrm{~nm}$ ratio of indo-1 fluorescence revealed that indomethacin further increased $\left[\mathrm{Ca}^{2+}\right]_{i}$ beyond the level of the bradykinininduced sustained elevation of $\left[\mathrm{Ca}^{2+}\right]_{i}$ (bottom trace in Fig. 4a).

The influence of indomethacin on $\left[\mathrm{Ca}^{2+}\right]_{\mathrm{i}}$ change induced by $20 \mathrm{mM} \mathrm{K}^{+}$was examined as shown in Fig. $4 \mathrm{~b}$. The increase in $\left[\mathrm{Ca}^{2+}\right]_{i}$ during the application of indomethacin was not significant.

Although the results are not shown, the indomethacin effect was also examined using fura-2 and Calcium Green. The ratio of fura-2 fluorescence excited at $342 \mathrm{~nm}$ to that at $380 \mathrm{~nm}$, which normally represents the $\left[\mathrm{Ca}^{2+}\right]_{\mathrm{i}}$ level in fura-2 fluorometry, was either unaltered or decreased during application of indomethacin. This may result from modification of the fura-2 fluorescence ratio in a misleading manner since indomethacin absorbs more light at $342 \mathrm{~nm}$ than at $380 \mathrm{~nm}$. When Calcium Green-1 was employed, the fluorescence intensity changed in a manner similar to that shown with indo-1 (Fig. 4a). Because both the excitation and emission wavelengths (470 and $530 \mathrm{~nm}$, respectively) of Calcium Green are apart from the absorption bands of indomethacin, the result with Calcium Green-1 is reliable. Considering these results all together, the data with fura- 2 were discarded.

\section{DISCUSSION}

\section{Potentiation by indomethacin of agonist-evoked $C A$ secretions}

It was found in this study that indomethacin greatly potentiated muscarine-, bradykinin- or histamine-evoked CA secretion in the rat adrenal medulla (Fig. 1). In contrast, indomethacin increased high- $\mathrm{K}^{+}$- or nicotineevoked CA secretion only to the extent comparable with the amount of secretion induced by indomethacin alone. The use of indomethacin at concentrations between 25 and $200 \mu \mathrm{M}$ is of particular interest since it significantly increases receptor-mediated secretions, whereas indomethacin at such concentrations has no substantial effect on either basal secretion or secretions evoked by depolar- izing agents. This may be potentially useful for distinguishing intracellular processes induced by various secretagogues in chromaffin cells.

The mechanism by which indomethacin potentiates agonist-evoked $C A$ secretion

In cells loaded with indo-1, the elevated $\left[\mathrm{Ca}^{2+}\right]_{i}$ due to bradykinin stimulation was further increased during application of indomethacin with a time course similar to that observed in secretion experiments (Fig. 4a). On the other hand, high- $\mathrm{K}^{+}$-induced increase in $\left[\mathrm{Ca}^{2+}\right]_{\mathrm{i}}$ was not significantly altered by $200 \mu \mathrm{M}$ indomethacin (Fig. 4b). These are compatible with the results of secretion experiments. Therefore, the potentiation of CA secretion seems to be directly correlated with the indomethacin-induced increase in $\left[\mathrm{Ca}^{2+}\right]_{\mathrm{i}}$. Although rat chromaffin cells possess intracellular $\mathrm{Ca}^{2+}$ stores that release $\mathrm{Ca}^{2+}$ following receptor stimulation, this $\mathrm{Ca}^{2+}$ poorly contributes to $\mathrm{CA}$ secretion when the medium contains $\mathrm{Ca}^{2+}$ at normal concentrations (26). Thus, the indomethacin-induced increase in $\left[\mathrm{Ca}^{2+}\right]_{i}$ is thought to be associated with an increased $\mathrm{Ca}^{2+}$ entry. This view is consistent with the fact that both the sustained component of bradykinin-evoked secretion and its increase by indomethacin were inhibited (Fig. 3e) by $\mathrm{Ni}^{2+}$ which inhibits receptor-mediated $\mathrm{Ca}^{2+}$ entry (25).

Nifedipine, which selectively inhibits voltage-gated $\mathrm{Ca}^{2+}$ channels in this preparation (3), only slightly affected the indomethacin-mediated potentiation of bradykinin-evoked secretion (Fig. 3d).

These results suggest that the receptor-mediated $\mathrm{Ca}^{2+}$ entry may be promoted by indomethacin. This may explain why indomethacin is particularly effective for promoting receptor-mediated CA secretions. Namely, indomethacin which may weakly stimulate $\mathrm{Ca}^{2+}$ entry even in the absence of receptor agonists strongly activates the receptor-mediated $\mathrm{Ca}^{2+}$ entry when it cooperates with receptor stimulations. Indomethacin may exert its action from the cell interior because the time course of the fluorescence decrease which indicates the accumulation of indomethacin in the intracellular space (top and middle traces in Fig. 4a) is similar to that of the increase in CA secretion during indomethacin application (Fig. 2b).

Indomethacin is widely used as a cyclooxygenase inhibitor. Some investigators have tested this effect on secretory responses. Sasakawa et al. (16) reported that indomethacin did not affect carbamylcholine-evoked CA secretion in bovine chromaffin cells. Yamada et al. (17) found that pretreatment with indomethacin slightly reduced CA secretion from perfused dog adrenal glands stimulated by acetylcholine or nicotine. These results are not in accordance with the present result. However, there are some difficulties in making such a comparison because 
the range of indomethacin concentration used in this study is higher than those in the above studies. Furthermore, chromaffin cells derived from various animal species may not be alike; in bovine chromaffin cells, for instance, receptor-mediated $\mathrm{Ca}^{2+}$ entry mechanism is known to be poorly developed $(27,28)$.

Arachidonic acid and $\mathrm{PGE}_{2}$ are the substrate and one of products in cyclooxygenase metabolism. Effects of these agents on secretory responses in chromaffin cells have also been examined by various investigators. $\mathrm{PGE}_{2}$ induced $C A$ secretion $(17-20)$ and potentiated secretions evoked by various secretagogues $(17,18,21) . \mathrm{PGE}_{2}$ also induced an increase in $\left[\mathrm{Ca}^{2+}\right]_{i}$ due to the promotion of $\mathrm{Ca}^{2+}$ entry (29). These $\mathrm{PGE}_{2}$ effects somewhat resemble those shown, in the present study, with indomethacin rather than those with $\mathrm{PGE}_{2}$. $\mathrm{PGE}_{2}$ applied to the present preparation did not affect either bradykinin-evoked secretion or its increase by indomethacin (Fig. 3b), although a very weak secretion was evoked by $\mathrm{PGE}_{2}$ alone as reported in previous papers $(17-20)$.

Despite a number of previous studies $(12-16)$, the role of arachidonic acid on secretory responses in chromaffin cells has not been established until now. In the present study, bradykinin-evoked secretion was not affected by the presence of arachidonic acid (Fig. 3c).

Although it is difficult to discuss these scattered facts in a consistent way, these results as a whole argue against the idea that the indomethacin effect described here originates from either the reduced production of $\mathrm{PGE}_{2}$ or the accumulation of arachidonic acid due to the inhibition of cyclooxygenase activity by the drug. This is supported by the fact that another cyclooxygenase inhibitor, ibuprofen, did not mimic the indomethacin effect (Fig. 3a). As one possibility, indomethacin may act as an activator of $\mathrm{Ca}^{2+}$ channels involved in the receptor-mediated $\mathrm{Ca}^{2+}$ entry. If this is proven as a novel action of indomethacin in future studies, it may be utilized to identify a class of $\mathrm{Ca}^{2+}$ channels that are activated after receptor stimulation in chromaffin cells and other cell types.

\section{Acknowledgments}

This study was supported in part by Grants-in-Aid (06670050 and 07308074) for Scientific Research from the Ministry of Education, Science, Sports and Culture of Japan.

\section{REFERENCES}

1 Yoshizaki T: Effect of histamine, bradykinin and morphine on adrenaline release from rat adrenal gland. Jpn J Pharmacol 23, $695-699$ (1973)

2 Wakade AR and Wakade TD: Contribution of nicotinic and muscarinic receptors in the secretion of catecholamines evoked by endogenous and exogenous acetylcholine. Neuroscience 10, 973-978 (1983)

3 Warashina A, Fujiwara N and Shimoji K: Characteristics of nicotinic and muscarinic secretory responses in the rat adrenal medulla studied by real-time monitoring of catecholamine release. Biomed Res 10, 157-164 (1989)

4 Warashina A, Fujiwara N and Shimoji K; Bradykinin-induced calcium mobilization and catecholamine secretion in rat adrenal medullary cells. Biomed Res 11, 219-229 (1990)

5 Warashina A: Calcium mobilization and catecholamine secretion in histamine-stimulated rat adrenal medullary cells. Biomed Res 13, 415-421 (1992)

6 Borges R: Ionic mechanism involved in the secretory effects of histamine in the rat adrenal medulla. Eur J Pharmacol 241, $189-194$ (1993)

7 Forsberg EJ, Rojas E and Pollard HB: Muscarinic receptor enhancement of nicotine-induced catecholamine secretion may be mediated by phosphoinositide metabolism in bovine adrenal chromaffin cells. J Biol Chem 261, 4915-4920 (1986)

8 Noble EP, Bommer M, Sincini E, Costa T and Herz A: $\mathrm{H}_{1-}$ Histaminergic activation stimulates inositol-1-phosphate accumulation in chromaffin cells. Biochem Biophys Res Commun $135,566-573$ (1986)

9 Berridge MJ and Irvine RF: Inositol trisphosphate, a novel second messenger in cellular signal transduction. Nature $\mathbf{3 1 2}$, 315-321 (1984)

10 Frye RA and Holz RW: Phospholipase $A_{2}$ inhibitors block catecholamine secretion and calcium uptake in cultured bovine adrenal medullary cells. Mol Pharmacol 23, 547-550 (1983)

11 Wada A, Sakurai S, Kobayashi H, Yanagihara N and Izumi F: Suppression by phospholipase $A_{2}$ inhibitors of secretion of catecholamines from isolated adrenal medullary cells by suppression of cellular calcium uptake. Biochem Pharmacol 32, $1175-1178$ (1983)

12 Nishibe S, Ogawa M, Murata A, Nakamura K, Hatanaka T, Kambayashi $\mathbf{J}$ and Kosaki G: Inhibition of catecholamine release from isolated adrenal medullary cells by various inhibitors: possible involvement of protease, calmodulin and arachidonic acid. Life Sci 32, 1613-1620 (1983)

13 Frye RA and Holz RW: The relationship between arachidonic acid release and catecholamine secretion from cultured bovine adrenal chromaffin cells. J Neurochem 43, 146-150 (1984)

14 Morgan A and Burgoyne RD: Relationship between arachidonic acid release and $\mathrm{Ca}^{2+}$-dependent exocytosis in degitonin-permeabilized bovine adrenal chromaffin cells. Biochem J 269, $521-526$ (1990)

15 Rindlisbacher B, Sidler MA, Galatioto LE and Zahler P: Arachidonic acid liberated by diacylglycerol lipase is essential for the release mechanism in chromaffin cells from bovine adrenal medulla. J Neurochem 54, 1247-1252 (1990)

16 Sasakawa N, Yamamoto S and Kato S: Effects of inhibitors of arachidonic acid metabolism on calcium uptake and catecholamine release in cultured adrenal chromaffin cells. Biochem Pharmacol 33, 2733-2738 (1984)

17 Yamada S, Morita K, Dohi T and Tsujimoto A: A modulating role of prostaglandins in catecholamine release by perfused dog adrenal glands. Eur J Pharmacol 146, 27-34 (1988)

18 Koyama Y, Kitayama S, Dohi T and Tsujimoto A: Evidence that prostaglandins activate calcium channels to enhance basal and stimulation-evoked catecholamine release from bovine adrenal chromaffin cells in culture. Biochem Pharmacol 37, $1725-1730$ (1988)

19 Karaplis AC, Funk CD and Powell WS: Binding of prostaglan- 
din $E_{2}$ to cultured bovine adrenal chromaffin cells and its effect on catecholamine secretion. Biochim Biophys Acta 1010, $369-376$ (1989)

20 Plevin R, Owen PJ, Marriott DB, Jones JA and Boarder MR: Role of phosphoinositide turnover and cyclic AMP accumulation in prostaglandin-stimulated noradrenaline release from cultured adrenal chromaffin cells. J Pharmacol Exp Ther 252, 1296- 1303 (1990)

21 Tanaka $T$, Yokohama $H$, Negishi $M$, Hayashi $H$, Ito $S$ and Hayaishi $O$ : Synergistic effect of prostaglandin $E_{2}$ and oubain on catecholamine release from cultured bovine adrenal chromaffin cells. J Neurochem 54, 86-95 (1990)

22 Warashina A: Properties of the sustained component of agonist-evoked catecholamine secretion in rat adrenal chromaffin cells. Jpn J Physiol 45, S19 (1995)

23 Fujiwara N, Warashina A and Shimoji K: Characterization of low $\mathrm{pH}$-induced catecholamine secretion in the rat adrenal medulla. J Neurochem 62, 1809 - 1815 (1994)

24 Grynkiewicz G, Poenie M and Tsien RY: A new generation of $\mathrm{Ca}^{2+}$ indicators with greatly improved fluorescence properties. J Biol Chem 260, 3440-3450 (1985)
25 Yamagami $\mathrm{K}$, Nishimura $\mathrm{S}$ and Sorimachi $\mathrm{M}$ : Internal $\mathrm{Ca}^{2-}$ mobilization by muscarinic stimulation from adrenal chromaffin cells only in the presence of $\mathrm{Ca}^{2+}$ influx. $\mathrm{J}$ Neurochem 57, $1681-1689$ (1991)

26 Warashina A and Fujiwara N: Properties of intracellular calcium stores and their role in receptor-mediated catecholamine secretion in rat adrenal chromaffin cells. Biol Signals 4, 195-205 (1995)

27 Cheek TR and Burgoyne RD: Effect of activation of muscarinic receptors on intracellular free calcium and secretion in bovine adrenal chromaffin cells. Biochim Biophys Acta 846, 167-173 (1985)

28 Kao L-S and Schneider AS: Muscarinic receptors on bovine chromaffin cells mediate a rise in cytosolic calcium that is independent of extracellular calcium. J Biol Chem 260, 2019-2022 (1985)

29 Ito S, Mochizuki-Oda N, Hori K, Ozaki K, Miyakawa A and Negishi M: Characterization of prostaglandin $\mathrm{E}_{2}$-induced $\mathrm{Ca}^{2+}$ mobilization in single bovine adrenal chromaffin cells by digital image microscopy. J Neurochem 56, 531-540 (1991) 